\title{
Obituary: Assoc. Prof. Vladimír Balek
}

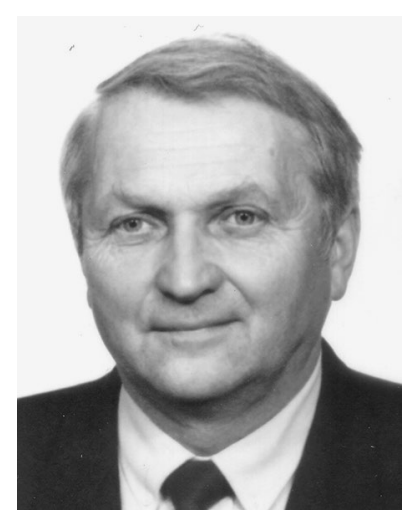

Associate Professor Vladimír Balek, D.Sc. passed away on January 9,2021 , at the age of 80 . This was after a long scientific career of nearly 50 years in the field of thermal analysis where he became one of its pioneers.

Vladimír Balek (1940-1921) graduated from the Czech Technical University (1961) and obtained a Ph.D. degree at Moscow State University (1967). He worked at the Faculty of Science, Charles University in Prague, and then in the Nuclear Institute in Řež.

He was fluent in Russian, English, French and Spanish and became famous as a professional guide at home and abroad. He became a co-founder of OSTA - the Czech group of thermal analysis at the turn of the seventies and was its second chairman (1972-1986). He developed the emerging field of thermal analysis and was an architect of ETA (emanation thermal analysis). He has always been part of a large group of enthusiasts promoting thermal analysis and particularly pioneered as an innovator a new branch of structural diagnostic methods (as ETA) when he laid its theoretical foundations in terms of a structural investigative approach. He became a co-designer of the ETA device, which became part of the Netzsch company's commercial offer and proposed its mathematical model within the processes of releasing inert gas from a doped multiphase system of solids with changing surfaces of reacting particles, including the account of changes due to diffusion resulting from physicochemical reactions. He has long been a member of the editorial boards of Thernochimica Acta (1984-1993) and the regional editor of the Journal of Thermal Analysis (1995-2000) as well as the affiliate councilor of ICTAC (1986-1994). He has written three professional books and hundreds of articles and achieved a VIP H-index in excess of twenty-five. He received a number of awards such as the Russian Kurnak Medal 1985, German Netzsch/GEFTA 1988, the American NATAS 1990 and the Hungarian JTAC 2002. He was a co-chairman and major promotor of the 8th ICTAC Conference in Bratislava 1985. He became an invited lecturer at various conferences and left behind a number of promising followers.

Prof. Balek spent a considerable time in abroad. Apart from his study years in Moscow, he stayed frequently at National Institute for Inorganic Materials in Tsukuba, Japan (now NIMS). One of his main objectives was promotion of international collaboration in the field of thermal analysis. He enjoyed traveling and with Jaroslav spent several weeks on round trip in USA. 


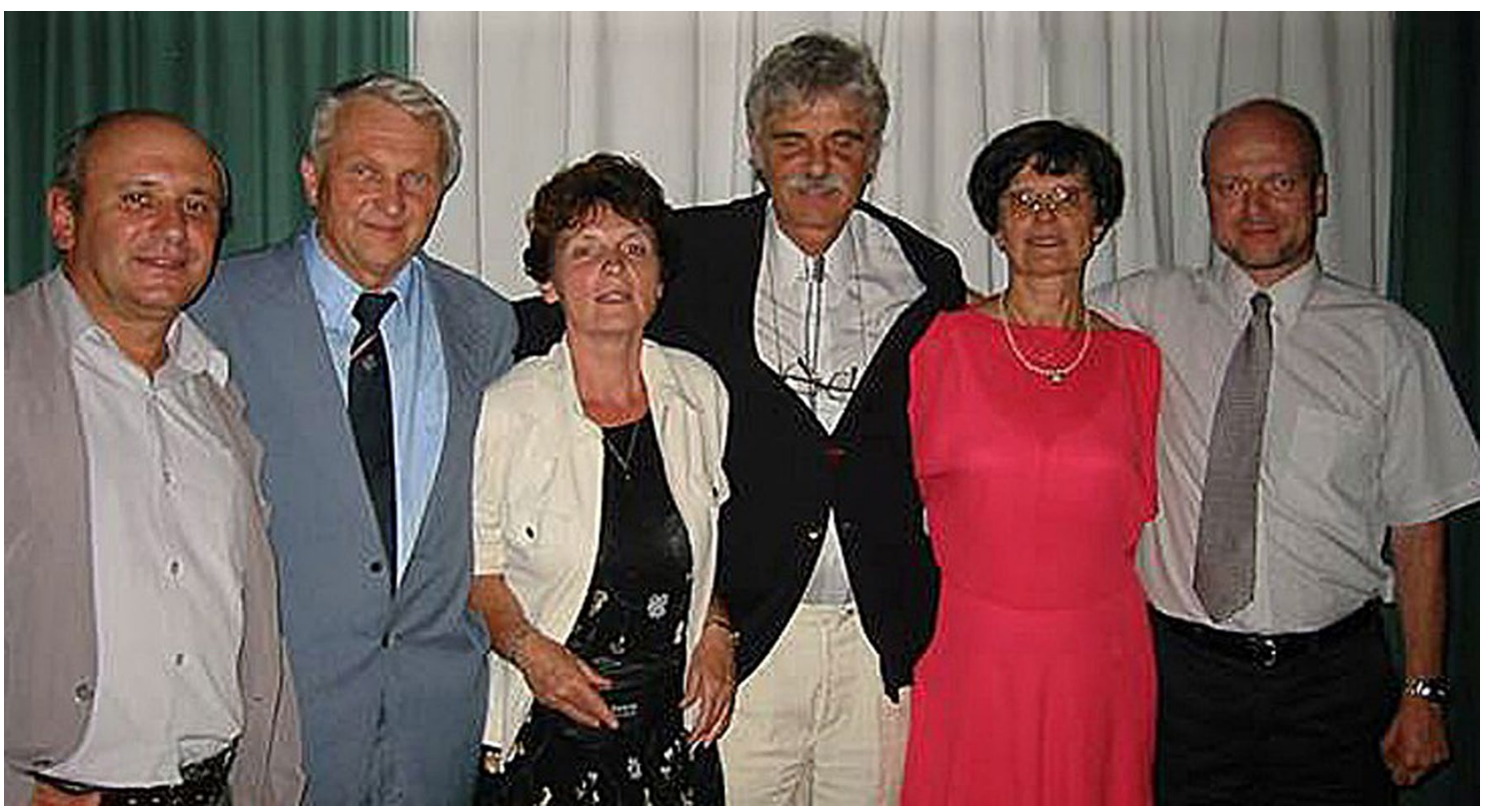

P. Šimon, V. Balek, J. Kovářová, J. Šesták, K. Györyová, J. Málek

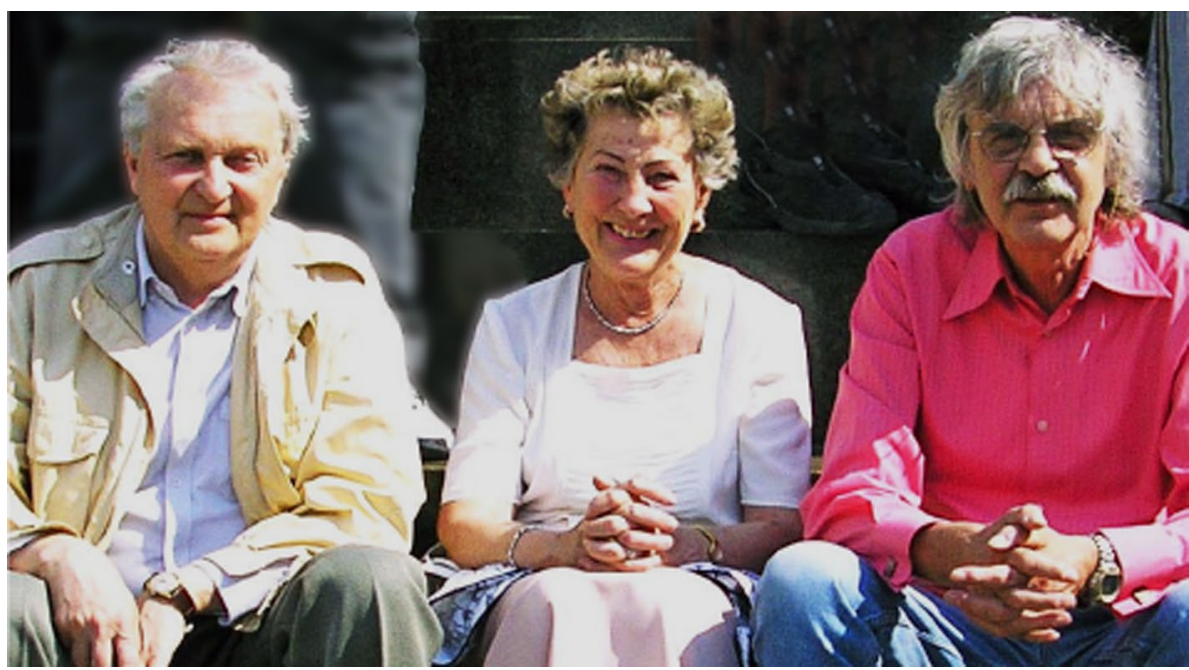

V. Balek. J. Šimon, J. Šesták

The research work was for him much more than a job. We will miss him very much.
Prof. Jaroslav Šesták, former chair of Czech Thermal Analysis Group, University of West Bohemia in Plzeň

Prof. Jiří Málek, ICTAC Affiliated councilor for Czechia, Pardubice University

Prof. Peter Šimon, ICTAC Affiliated councilor for Slovakia, Slovak Technical University in Bratislava

Publisher's Note Springer Nature remains neutral with regard to jurisdictional claims in published maps and institutional affiliations. 